\title{
Synthesis of Fe(III) Complexes as Antioxidants and DNA Cleavage Protectors
}

\author{
Prakash Naik HR ${ }^{1}$, Rajappa JJ ${ }^{2}$, Karmakar B ${ }^{2}$, Raja Naika $\mathrm{H}^{3}$, Ramachandra Naik $\mathbf{M}^{4^{*}}$, Ramesh TP $^{5}$, Pompee Chanda ${ }^{6}$, Poonam Gusain ${ }^{7}$ and Bhojya Naik HS ${ }^{1}$ \\ ${ }^{1}$ Department of Studies and Research in Industrial chemistry, Kuvempu University, Shankaraghatta-577 451, India \\ ${ }^{2}$ Division of Natural Resource Management (Agroforestry), ICAR Research Complex for NEH Region Umiam (Barapani), Meghalaya-793103, India \\ ${ }^{3}$ Department of Studies and Research in Environmental Science, Tumkur University, Tumkur-572103, India \\ ${ }^{4}$ Department of Studies and Research in Applied Botany, School of Biological Sciences, Kuvempu University, Shankaraghatta-577451, India \\ ${ }^{5}$ Department of Biochemistry and Molecular Biology, Penn State College of Medicine, Pennsylvania University, Hershey, USA \\ ${ }^{6}$ Department of Veterinary Microbiology, Indian Veterinary Research Institute-Regional Station, Kolkata-700037, India \\ ${ }^{7}$ Department of Botany and Microbiology, HNB Garhwal University, Srinagar, Garhwal 246174, Uttarakhand, India
}

"Corresponding author: Ramachandra Naik M, Department of Studies and Research in Applied Botany, School of Biological Sciences, Kuvempu University, Shankaraghatta-577451, India, Tel: +9196207 20591; E-mail: rcnaik1@gmail.com

Received: March 13, 2018; Accepted: March 22, 2018; Published: April 13, 2018

Copyright: @ 2018 Prakash Naik HR, et al. This is an open-access article distributed under the terms of the Creative Commons Attribution License, which permits unrestricted use, distribution, and reproduction in any medium, provided the original author and source are credited.

\begin{abstract}
Synthesis of quinolines containing selenium and sulfur bioactive ligands and their $\mathrm{Fe}(\mathrm{III})$ complexes is described. Invitro antioxidant activity were evaluated against, 1,1-diphenyl-2-picryl-hydrazil (DPPH), hydrogen peroxide, superoxide anion radical, reducing power and hydroxyl radical $(\cdot \mathrm{HO})$. At different concentrations, $(20-60 \mu \mathrm{g} / \mathrm{mL})$ the total antioxidant activity of synthesized ligands showed 71,75 and $83 \%$ and complexes showed $76,85,94 \%$ of inhibition. Where at the same concentration and experimental condition the standard antioxidant such as butylated hydroxyanisole (BHA), butylated hydroxytoluene (BHT), and a-tocopherol exhibited 94,95 and $63 \%$ inhibitions on peroxidation of linoleic acid emulsion. In support to antioxidants, DNA cleavage investigation of complexes leads to protective effect on DNA cleavage. Hence, this study confirms ligands and their Fe(III)-chelator as antioxidants as well as protect against DNA cleavage.
\end{abstract}

Keywords: Antioxidant; DNA damage; Free radicals; Peroxidase; Quinone

\section{Introduction}

Majority of the diseases/disorders are mainly linked to oxidative stress due to free radicals [1]. Free radicals are fundamental to any biochemical process and represent an essential part of aerobic life and metabolism [2]. The most common reactive oxygen species (ROS) include superoxide $\left(\mathrm{O}_{2}{ }^{--}\right)$anion, hydrogen peroxide $\left(\mathrm{H}_{2} \mathrm{O}_{2}\right)$, peroxyl $\left(\mathrm{ROO}^{-}\right)$radicals, and reactive hydroxyl $(\mathrm{OH} \cdot)$ radicals. The nitrogen derived free radicals are nitric oxide (NO) and peroxynitrite anion (ONOO). ROS have been implicated in over a hundreds of diseases states which range from arthritis and connective tissue disorders to carcinogenesis, aging, physical injury, infection and acquired immunodeficiency syndrome [3]. In treatment of these diseases, antioxidant therapy has gained an immense importance. To overcome this problem, current research is now directed towards finding synthetic and naturally occurring antioxidants of plant origin.

Recent studies on intramolecularly stabilized organoselenium and sulfur compounds show that the Se and $S$ interactions play an important role in the catalytic antioxidant activity [4]. Since, Se resembles sulfur (S) in many of its properties [5], they may be considered to be isosteric [6]. The biological and pharmaceutical activities of different selenium compounds are of special interest because it function found in the active site of a large selenium dependent enzymes, such as (GSH-Px) [7,8], modification of metal toxicity [9] and prevention of cancer [10].
Further, in living organisms free radical formation and the free radical defense system are closely related to metal ions and complexes $[11,12]$. Iron is one of the essential element involved in several biological functions, acting as a catalytic component of many metalloenzymes, including SOD. Transition metal complexes of $\mathrm{Mn}(\mathrm{II}) / \mathrm{Mn}$ (III), $\mathrm{Cu}(\mathrm{II})$ and $\mathrm{Fe}(\mathrm{III})$ have notably shown important antioxidant properties, namely SOD mimetic activity [13-15]. Fenton reaction describes $\mathrm{Fe}$ (II) induced hydroxyl radical formation [16-18] and other transition metal ions $(\mathrm{V}, \mathrm{Cr})$ take part in fenton-like reactions $[19,20]$.

Previous studies have demonstrated that chemical modifications in the ring size, donor atoms and substituents on the complexes, may have profound effects both on the stability and the antioxidant activities $[21,22]$. These, antioxidant supplement may reduce oxidative damage [23]. Since, the damage occurs invivo by hydroxyl radical generated in metal-mediated Fenton-type reactions [24]. Herein support to free radical mechanism in antioxidant activity we carried out DNA cleavage behavior in presence hydrogen peroxide, the results leads to DNA cleavage protector.

To the best of our knowledge, the metal complexes with ligand containing sulfur and selenium for antioxidants are not reported yet. So, in view of biological importance of selenium and sulfur, in the present work we describe iron(III) complexes of substituted quinoline containing sulfur and selenium focusing on their possible application as antioxidants and DNA cleavage protectors. 
Citation: Prakash Naik HR, Rajappa JJ, Karmakar B, Raja Naika H, Ramachandra Naik M, et al. (2018) Synthesis of Fe(III) Complexes as Antioxidants and DNA Cleavage Protectors. Nat Prod Chem Res 6: 317. doi:10.4172/2329-6836.1000317

Page 2 of 8

\section{Experimental}

\section{Chemicals}

All reagents and solvents used were $\mathrm{AR}$ grade, commercially purchased. Ammonium hexa fluoro phosphate $\left(\mathrm{NH}_{4} \mathrm{PF}_{6}\right)$, and tris$\mathrm{HCl}$ buffer, Ferric chloride, a-tocopherol, 1,1-diphenyl-2-picrylhydrazyl (DPPH), nicotinamide adenine dinucleotide (NADH), butylated hydroxyanisole (BHA), butylated hydroxytoluene (BHT), and trichloracetic acid (TCA) were purchased from Sigma (SigmaAldrich, E. Merck, Himedia, Qualigens, Mumbai, India) and solution was prepared using deionised double distilled water. Melting points were determined in an open capillary tube and are uncorrected. IR spectra were recorded in $\mathrm{KBr}$ pellets on Perkin-Elmer 157 IR spectrophotometer. ${ }^{1} \mathrm{H}$ NMR spectra were recorded in DMSO- $\mathrm{d}_{6}$ on EM-390 (300 MHz) NMR spectrometer, Electronic spectra were recorded on 835 Perkin-Elmer UV/Vis spectrophotometers using Nujol mull technique. Mass spectra were recorded on MASPEC low resolution instrument operating at $70 \mathrm{eV}$ and UV-Visible spectra were recorded using SHIMADZU, UV-1650 PC model.

General procedure for the synthesis of 2-\{[(2mercaptoquinolin-3-yl) methylene] amino\} benzoic acid (4a) and $2-\{[(2$-selenoquinolin-3-yl) methylene $]$ amino $\}$ benzoic acid (4b)

The mixture of 2-mercapto or 2-selenoquinoline-3-carbaldehyde (2a or $3 \mathrm{a})(1.89 \mathrm{~g}, 2.36 \mathrm{~g}, 0.01 \mathrm{~mol})$ and anthranilic acid $(1.37 \mathrm{~g}, 0.01 \mathrm{~mol})$ were stirred and refluxed for 1-2 hrs. The completion of reaction was monitored by TLC. Then the reaction mass cooled and was poured into crushed ice. The obtained yellow or brown colored precipitate was filtered and recrystallized from methanol.

\section{Spectral data of 2-\{[(2-mercaptoquinolin-3-yl) methylene $]$ amino\} benzoic acid (4a)}

Yellow solid, Yield $92 \%, \mathrm{mp} .167^{\circ} \mathrm{C}$; IR (v) (KBr) $\mathrm{cm}^{-1}$; 3020(C-H, Ar-H); 1668 (C=N); $1263(\mathrm{COOH}) ; 1892(\mathrm{CHN}) ; 2593(\mathrm{~S}-\mathrm{H}) ;{ }^{1} \mathrm{H}$ NMR (DMSO d 6 ), $\delta$ 7.1-8.3 (m, 8H, Ar-H), $8.7\left(\mathrm{~s},{ }^{1} \mathrm{H}, \mathrm{CHN}\right), 10.1(\mathrm{~s}$, $\left.{ }^{1} \mathrm{H}, \mathrm{SH}\right), 11.2\left(\mathrm{~s},{ }^{1} \mathrm{H}, \mathrm{COOH}\right)$, Elemental anlysis, Found: C-66.21; $\mathrm{H}-3.94 ; \mathrm{N}-9.10$. Calculated for $\mathrm{C}_{17} \mathrm{H}_{12} \mathrm{~N}_{2} \mathrm{O}_{2} \mathrm{~S}: \mathrm{C}-66.22 ; \mathrm{H}-3.92 ; \mathrm{N}-9.08$.

\section{Spectral data of 2-\{[(2-selenoquinolin-3-yl) methylene $]$ amino benzoic acid (4b)}

Brown solid, Yield 85\%, mp. $192^{\circ} \mathrm{C}$; IR (v) (KBr) cm ${ }^{-1}$; $3015(\mathrm{C}-\mathrm{H}$, Ar-H); $1658(\mathrm{C}=\mathrm{N}) ; 1278(\mathrm{COOH}) ; 1881(\mathrm{CHN}) ; 2585(\mathrm{Se}-\mathrm{H}) ;{ }^{1} \mathrm{H}$ NMR (DMSO d 6 ), $\delta 7.0-8.1\left(\mathrm{~m}, 8 \mathrm{H}\right.$, Ar-H), $8.9\left(\mathrm{~s},{ }^{1} \mathrm{H}, \mathrm{CHN}\right), 10.5(\mathrm{~s}$, $\left.{ }^{1} \mathrm{H}, \mathrm{Se}-\mathrm{H}\right), 11.8\left(\mathrm{~s},{ }^{1} \mathrm{H}, \mathrm{COOH}\right)$, Elemental anlysis, Found:C-57.45; $\mathrm{H}-3.42$; N-7.88. Calculated for $\mathrm{C}_{17} \mathrm{H}_{12} \mathrm{~N}_{2} \mathrm{O}_{2}$ Se:C-57.48; H-3.40; N-7.89.

\section{General procedure for the synthesis of $5 a$ and $5 b$}

The compounds $4 \mathrm{a}(3.08 \mathrm{~g}, 0.01 \mathrm{~mol})$ and $4 \mathrm{~b}(3.08 \mathrm{~g}, 0.01 \mathrm{~mol})$ were dissolved in $20-25 \mathrm{ml}$ of PPA, than refluxed at $120^{\circ} \mathrm{C}$ for $3-4 \mathrm{hrs}$. The cooled reaction mass poured into crushed ice and basified with sodium hydrogen carbonate. The obtained precipitate were filtered and recrystallized from methanol.
6-Mercapto-1H-benzazepino[3,4-c] quinolin-1-one (MBAQ) (5a)

Yellow solid, Yield $87 \%, \mathrm{mp} .176^{\circ} \mathrm{C}$; IR $(v)(\mathrm{KBr}) \mathrm{cm}^{-1} ; 3024(\mathrm{C}-\mathrm{H}$, Ar-H); 1672 (C=N); 1620 (C=O); 1887 (CHN); 2576 (S-H); ${ }^{1} \mathrm{H}$ NMR $\left(\mathrm{DMSO} \mathrm{d}_{6}\right), \delta$ 7.3-8.0 (m, 8H, Ar-H), $8.8\left(\mathrm{~s},{ }^{1} \mathrm{H}, \mathrm{CHN}\right), 10.4\left(\mathrm{~s},{ }^{1} \mathrm{H}\right.$, $\mathrm{SH})$, Elemental anlysis, Found:C-70.32; H-3.48; N-9.64. Calculated for $\mathrm{C}_{17} \mathrm{H}_{10} \mathrm{~N}_{2} \mathrm{O}$ S:C-70.33; H-3.47; N-9.65.

\section{6-Seleno-1H-benzazepino[3,4-c] quinolin-1-one (SBAQ) (5b)}

Brown solid, Yield $79 \%, \mathrm{mp} .205^{\circ} \mathrm{C}$; IR (v) (KBr) $\mathrm{cm}^{-1} ; 3019(\mathrm{C}-\mathrm{H}$, Ar-H); $1661(\mathrm{C}=\mathrm{N}) ; 1631(\mathrm{C}=\mathrm{O}) ; 1895(\mathrm{CHN}) ; 2598(\mathrm{Se}-\mathrm{H}) ;{ }^{1} \mathrm{H}$ NMR $\left(\mathrm{DMSO} \mathrm{d}_{6}\right), \delta$ 7.0-8.1 (m, 8H, Ar-H), $8.7\left(\mathrm{~s},{ }^{1} \mathrm{H}, \mathrm{CHN}\right), 10.8\left(\mathrm{~s},{ }^{1} \mathrm{H}, \mathrm{Se}-\right.$ $\mathrm{H})$, Elemental anlysis, Found: C-60.54; H-2.87; N-8.33.Calculated for $\mathrm{C}_{17} \mathrm{H}_{10} \mathrm{~N}_{2} \mathrm{O}$ Se: C-60.55; H-2.89; N-8.31.

\section{Preparation of $\mathrm{Fe}(\mathrm{II})$ metal complexes $\left[\mathrm{Fe}(\mathrm{MBAQ})_{3}\right]\left(\mathrm{PF}_{6}\right)_{3}$} (6a) and $\left[\mathrm{Fe}\left(\mathrm{SBAQ}_{3}\right]\left(\mathrm{PF}_{6}\right)_{3}(6 \mathrm{~b})\right.$

General procedure for the synthesis of complexes $6 a$ and $6 b$ : Ferric(III) nitrate monahydrate $(0.404 \mathrm{~g}, 0.001 \mathrm{M})$ and 6-mercapto or 6-seleno-1H-benzazepino[3,4-c] quinolin-1-one $(0.870 \mathrm{~g}(5 \mathrm{a})$ or 1.011 $\mathrm{g}(5 \mathrm{~b}), 0.003 \mathrm{M}$ ) were dissolved in hot ethanolic solution in the molar ratio $1: 3$ and refluxed on water bath for $2 \mathrm{hr}$. The complexing mixture was cooled and precipitated by the addition of hot ethanolic solution of ammonium hexafluro phosphate $\left(\mathrm{NH}_{4} \mathrm{PF}_{6}\right)$ to filtrate. The complex was filtered and dried under vacuum before recrystallized from acetone-ether mixture.

\section{Complex $\left[\mathrm{Fe}(\mathrm{MBAQ})_{3}\right]\left(\mathrm{PF}_{6}\right)_{3}(6 \mathrm{a})$}

Pale brown solid, Yield $81 \%$, mp. $183^{\circ} \mathrm{C}$; IR (v) $(\mathrm{KBr}) \mathrm{cm}^{-1}$; 423, 753, 837, 1105, 1620, 1645, 1875, 3025. Elemental anlysis, Found:C-44.96; $\mathrm{H}-2.23$; Fe-4.12; N-6.16. Calculated for $\mathrm{C}_{51} \mathrm{H}_{30}$ $\mathrm{F}_{18} \mathrm{FeN}_{6} \mathrm{O}_{3} \mathrm{P}_{3} \mathrm{~S}_{3}: \mathrm{C}-44.98 ; \mathrm{H}-2.22 ; \mathrm{Fe}-4.10 ; \mathrm{N}-6.17$.

\section{Complex- $\left[\mathrm{Fe}(\mathrm{SBAQ})_{3}\right]\left(\mathrm{PF}_{6}\right)_{3}(6 \mathrm{~b})$}

Brown solid, Yield $73 \%, \mathrm{mp} .231^{\circ} \mathrm{C}$; IR (v) $(\mathrm{KBr}) \mathrm{cm}^{-1} ; 435,573,785$, 839, 1055, 1620, 1854, 1640, 3096. Elemental anlysis, Found:C-40.76; $\mathrm{H}-2.02$; Fe-3.73; N-5.61. Calculated for $\mathrm{C}_{51} \mathrm{H}_{30}$ $\mathrm{F}_{18} \mathrm{FeN}_{6} \mathrm{O}_{3} \mathrm{P}_{3} \mathrm{Se}_{3}: \mathrm{C}-40.77 ; \mathrm{H}-2.01 ; \mathrm{Fe}-3.72 ; \mathrm{N}-5.59$.

\section{Invitro antioxidant activity}

Total antioxidant activity of $[\mathrm{Fe}(\mathrm{MBAQ})]_{3}\left(\mathrm{PF}_{6}\right)_{3} \quad(6 \mathrm{a})$ and $\left[\mathrm{Fe}(\mathrm{SBAQ})_{3}\right]\left(\mathrm{PF}_{6}\right)_{3}(6 \mathrm{~b})$ : The antioxidant activity of complexes was determined according to the thiocyanate method [25]. An $10 \mathrm{mg}$ of both complexes was dissolved in $10 \mathrm{~mL}$ methanol, and a $10 \mathrm{mg}$ of both ligands were dissolved in $10 \mathrm{~mL}$ ethanol. Concentration of 20,40 , and $60 \mu \mathrm{g} / \mathrm{mL}$ of complexes and ligands or standards samples in $2.5 \mathrm{~mL}$ of potassium phosphate buffer $(0.04 \mathrm{M}, \mathrm{pH} 7.0)$ was added to $2.5 \mathrm{~mL}$ linoleic acid emulsion consists of $175 \mathrm{mg}$ of Tween-20, $155 \mathrm{~mL}$ of linoleic acid, and $0.04 \mathrm{M}$ of potassium phosphate buffer ( $\mathrm{pH} 7.0$ ) in potassium phosphate buffer $(0.04 \mathrm{M}, \mathrm{pH} 7.0)$. On the other hand, a 50 $\mathrm{mL}$ control consisted of $25 \mathrm{~mL}$ linoleic acid emulsion and $25 \mathrm{~mL}$ potassium phosphate buffer $(0.04 \mathrm{M}, \mathrm{pH} 7.0)$. The mixed solution was incubated at $37^{\circ} \mathrm{C}$. After the mixture was stirred, the peroxide value was determined by reading the absorbance at $500 \mathrm{~nm}$ after incubation. Therefore, high absorbance indicates high linoleic acid oxidation. The solutions without complexes, ligand or standard were used as blank 
samples. All data about total antioxidant activity are the averages of duplicate analyses. The inhibition of lipid peroxidation in percentage was calculated by following equation (1):

$\%$ Inhibition $=\left[\left(\mathrm{A}_{0}-\mathrm{A}_{1}\right) / \mathrm{A}_{0}\right] \times 100$

where $\mathrm{A}_{0}$ was the absorbance of the control reaction and $\mathrm{A}_{1}$ was the absorbance in the presence of the samples of $\left[\mathrm{Fe}(\mathrm{MBAQ})_{3}\right]$ and $\left[\mathrm{Fe}(\mathrm{SBAQ})_{3}\right]$ and their ligands $5 \mathrm{a}$ and $5 \mathrm{~b}[26]$.

\section{Reducing power}

The reducing power of ligands and complexes were determined according to the literature method [27]. The five concentrations of complexes $(20,40,60 \mu \mathrm{g} / \mathrm{mL})$ in $1 \mathrm{~mL}$ of distilled water were mixed with phosphate buffer $(2.5 \mathrm{~mL}, 0.2 \mathrm{M}, \mathrm{pH}$ 6.6) and potassium ferricyanide $\left[\mathrm{K}_{3} \mathrm{Fe}(\mathrm{CN})_{6}\right](2.5 \mathrm{~mL}, 1 \%)$. The mixture was incubated at $50^{\circ} \mathrm{C}$ for $20 \mathrm{~min}$. A portion $(2.5 \mathrm{~mL})$ of trichloroacetic acid $(10 \%)$ was added to the mixture, which was then centrifuged for $10 \mathrm{~min}$. The upper layer of solution $(2.5 \mathrm{~mL})$ was mixed with distilled water $(2.5$ $\mathrm{mL})$ and $\mathrm{FeCl}_{3}(0.5 \mathrm{~mL}, 0.1 \%)$. The absorbance was measured at 700 nm.

\section{Superoxide anion scavenging activity}

Measurements of superoxide anion scavenging activity were based on the method described [28]. Superoxide radicals are generated in PMS-NADH systems by oxidation of NADH and assayed by the reduction of Nitroblue Tetrazolium (NBT). In these experiments, the superoxide radicals were generated in $3 \mathrm{~mL}$ of Tris- $\mathrm{HCl}$ buffer (16 $\mathrm{mM}, \mathrm{pH} 8.0$ ) containing $1 \mathrm{~mL}$ of NBT (50 mM) solution, $1 \mathrm{~mL} \mathrm{NADH}$ (78 mM) solution, and a sample solution of complexes $(20,40,60$ $\mu \mathrm{g} / \mathrm{mL}$ ) in ethanol. The reaction started by adding $1 \mathrm{~mL}$ of Phenazine Metho Sulfate (PMS) solution $(10 \mathrm{mM})$ to the mixture. The reaction mixture was incubated at $25^{\circ} \mathrm{C}$ for $5 \mathrm{~min}$ and the absorbance was recorded at $560 \mathrm{~nm}$. L-Ascorbic acid was used as a control. The percentage inhibition of superoxide anion generation was calculated using the formula shown in Equation (1) [29].

\section{DPPH free radical scavenging activity}

The free radical scavenging activity was measured against 1,1diphenyl-2-picryl-hydrazil (DPPH) using the method of [30]. Briefly, 1 $\mathrm{ml}$ of $0.1 \mathrm{mM}$ solution of DPPH in ethanol was added to $3 \mathrm{~mL}$ of ligands and complexes in phosphate buffer at different concentrations $(20,40,60 \mu \mathrm{g} / \mathrm{mL})$. The mixture was shaken vigorously and allowed to stand at room temperature for $30 \mathrm{~min}$ and then the absorbance was measured at $517 \mathrm{~nm}$. The DPPH concentration $(\mathrm{mM})$ in the reaction medium was calculated from the following calibration curve, determined by linear regression $\left(\mathrm{R}^{2}: 0.9769\right)$ :

Absorbance $=104.09 \times\left[\mathrm{DPPH}^{*}\right]$

The DPPH radical concentration was calculated using the following equation (2):

$$
\text { DPPH Scavenging Effect }(\%)=100-\left[\left(A_{0}-A_{1} / A_{0}\right) \times 100\right]
$$

where $A_{0}$ was the absorbance of the control reaction and $A_{1}$ was the absorbance in the presence of the sample of complex $6 \mathrm{a}$ or $6 \mathrm{~b}$ and their respective ligands.

\section{Scavenging of hydrogen peroxide}

The ability of the scavenging effect of complexes and ligands to hydrogen peroxide was determined according to the reported method [31]. A solution of hydrogen peroxide $(40 \mathrm{mM})$ was prepared in phosphate buffer ( $\mathrm{pH}$ 7.4). Hydrogen peroxide concentration was determined spectrophotometrically from absorption at $230 \mathrm{~nm}$. Complexes $(20,40,60 \mu \mathrm{g} / \mathrm{mL})$ in ethanol and distilled water were added to a hydrogen peroxide solution $(0.6 \mathrm{~mL}, 40 \mathrm{mM})$. Absorbance of hydrogen peroxide at $230 \mathrm{~nm}$ was determined after 10 minutes against a blank solution. The percentage of scavenging of hydrogen peroxide was calculated using the equation (1):

\section{Hydroxyl radical (HO.) scavenging assay}

The ability of complexes and ligands to scavenge the hydroxyl radical generated by the Fenton reaction was measured according by modified method [32]. An $200 \mu \mathrm{L}$ of $10 \mathrm{mM} \mathrm{FeSO}_{4} \cdot 7 \mathrm{H}_{2} \mathrm{O}, 200 \mu \mathrm{L}$ of 10 $\mathrm{mM}$ EDTA and $200 \mu \mathrm{L}$ of $10 \mathrm{mM}$ 2-deoxyribose were mixed with 1.2 $\mathrm{mL}$ of $0.1 \mathrm{M}$ phosphate buffer ( $\mathrm{pH} 7.4$ ) containing $200 \mu \mathrm{L}$ of different concentration of compounds. Thereafter, $200 \mu \mathrm{L}$ of $10 \mathrm{mM} \mathrm{H}_{2} \mathrm{O}_{2}$ was added to the mixture before incubation for $4 \mathrm{~h}$ at $37^{\circ} \mathrm{C}$. Later, $1 \mathrm{~mL}$ of $2.8 \%$ TCA and $1 \mathrm{~mL}$ of $1 \%$ TBA were added and placed on a boiling water bath for $10 \mathrm{~min}$. Absorbance was recorded at $532 \mathrm{~nm}$.

\section{DNA cleavage experiments}

The experiments were performed in a volume of $20 \mathrm{ml}$ containing pUC19 DNA in $5 \mathrm{mmol} / \mathrm{L}$ phosphate buffer contained $10 \mathrm{mmol} / \mathrm{L}$ $\mathrm{NaCl}, \mathrm{pH} 7.4$, in the presence of different concentrations (200-400 $\mathrm{mmol} / \mathrm{L}$ ) of complexes. Immediately prior to irradiating the samples with UV light, $\mathrm{H}_{2} \mathrm{O}_{2}$ was added to a final concentration of $2.5 \mathrm{mmol} / \mathrm{L}$.

The reaction volumes were held in caps of polyethylene microcentrifuge tubes, which were placed directly on the surface of a trans-illuminator $(8000 \mathrm{~mW} / \mathrm{cm})$ at $360 \mathrm{~nm}$. The samples were irradiated for $5 \mathrm{~min}$ at room temperature. After irradiation, $4.5 \mathrm{ml}$ of a mixture containing $0.25 \%$ bromophenol blue, $0.25 \%$ xylene cyanol FF, and $30 \%$ glycerol was added to the irradiated solution. The samples were then analyzed by electrophoresis on a $1 \%$ agarose horizontal slab gel in Tris-borate buffer $(45 \mathrm{mmol} / \mathrm{L}$ Tris-borate, $1 \mathrm{mmol} / \mathrm{L}$ EDTA). Untreated pUC19 DNA was included as a control in each run of gel electrophoresis, which was carried out at $1.5 \mathrm{~V} / \mathrm{cm}$ for $15 \mathrm{~h}$. Gel was stained in ethidium bromide $(1 \mathrm{mg} / \mathrm{ml})$ and photographed under UV light [33].

\section{Results and Discussion}

Numerous condensed quinolines have various bioactivities, which render them valuable pharmacological activities as mentioned earlier and therefore, they are a useful material in drug research. Hence, in continuation of our study in developing condensed quinolines derivatives [34] due to their significant biological activities, it appeared expedient to synthesize a series of systematically condensed quinolines used as ligands for metal complexes.

\section{Characterization of ligands and their complexes}

The present study deals with the synthesis and evaluation of antioxidant activity of a new scaffold of iron complexes containing quinoline analogue bearing selenium ad sulfur. The starting compounds for the preparation of ligands obtained according to our reported procedures [34]. The ligands were synthesized via cyclization 
of $4 \mathrm{a}$ and $4 \mathrm{~b}$. The elemental analysis data and their spectral data are presented in the experimental section. The IR spectra of $5 \mathrm{a}$ and $5 \mathrm{~b}$ showed an absorption at $1672 \mathrm{~cm}^{-1}$ for $v(\mathrm{C}=\mathrm{N})$ vibration. It also shows absorption bands at $2576-2598 \mathrm{~cm}^{-1}$ for $\mathrm{S} / \mathrm{Se}-\mathrm{H}$ and the ${ }^{1} \mathrm{H}$ NMR spectral data of ligands $5 \mathrm{a}$ and $5 \mathrm{~b}$ showed singlet belongs to $\mathrm{S} / \mathrm{Se}-\mathrm{H}$ at $\delta 10.4$ and 10.8 respectively, these are the evidence for the formation of expected structure. Finally, the structure was confirmed by its mass spectrum through the appearance of molecular ion peak at $\mathrm{m} / \mathrm{z} 289[\mathrm{M}$ $+]$ and $336\left[\mathrm{M}^{+}\right]$(Scheme 1).

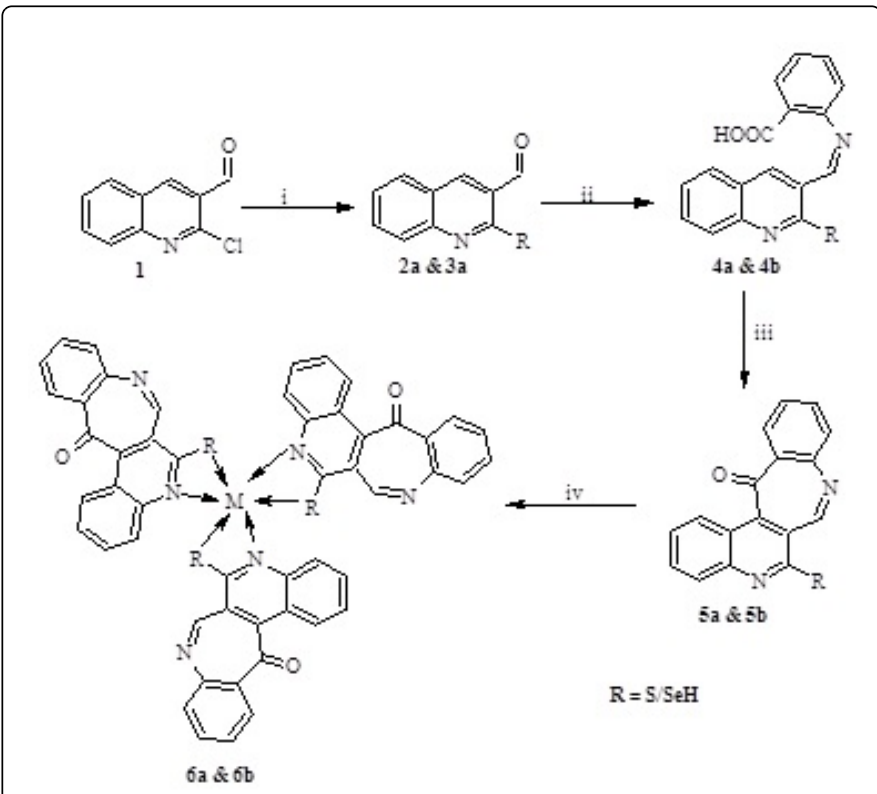

Scheme 1: Synthetic route carried out for the synthesis of ligands and their complexes. i) $\mathrm{Na}_{2} \mathrm{~S} / \mathrm{NaHSe}$, ii) 2 -amino benzoic acid reflux 1-2 hrs, iii) PPA, reflux 3-4 hrs, iv) Ferric(III) nitrate monohydrate ethanol reflux, add $\left(\mathrm{NH}_{4} \mathrm{PF}_{6}\right)$.

The elemental analysis data of complexes agreed with the theoretical values within the limit of experimental error. These new complexes are insoluble in water, but soluble in DMF, DMSO, and in buffer ( $\mathrm{pH} 7.2$ ) solution. The conductometric measurement values (28-58 $\mathrm{ohm}^{-1} \mathrm{~cm}^{-1} \mathrm{~mol}^{-1}$ ) in DMF indicate their electrolytic nature. The observed magnetic moment values (3.1-3.21 BM) for these complexes are in the same range as reported for the octahedrally coordinated $\mathrm{Fe}(\mathrm{III})$ ion $[35,36]$.

The IR spectra of ligands and complexes were recorded in the range of $4000-250 \mathrm{~cm}^{-1}$ on $\mathrm{KBr}$ pellets. The intense bands appeared for ligands at $1672 \mathrm{~cm}^{-1}$, is due to $v(\mathrm{C}=\mathrm{N})$ vibrations of quinoline nitrogen ring system. In $\left[\mathrm{Fe}(\mathrm{MBAQ})_{3}\right] \quad\left(\mathrm{PF}_{6}\right)_{3}$ and $\left[\mathrm{Fe}(\mathrm{SBAQ})_{3}\right] \quad\left(\mathrm{PF}_{6}\right)_{3}$ complexes, this band was shifted to $25-35 \mathrm{~cm}^{-1}$ indicate that nitrogen atom is involved in coordination of $\mathrm{Fe}(\mathrm{III})$ ion. Besides, the complexes show low frequency in the region $423-435 \mathrm{~cm}^{-1}$ and $450-470 \mathrm{~cm}^{-1}$ are assigned to $v(\mathrm{M}-\mathrm{N})$ and $v(\mathrm{M}-\mathrm{S} / \mathrm{Se})$ bands, respectively $[35,36]$. In addition, the IR spectrum of the $\mathrm{PF}_{6}$ salt of each complex showed a strong band in the region $841-846 \mathrm{~cm}^{-1}$ ascribable to the counter anion and this band was absent for the corresponding chloride salts [37].

The electronic spectra of ligands was characterized by prominent bands at $300 \mathrm{~nm}$ ascribable to the intramolecular $\pi-\pi^{*}$ transition. The spectra of $\mathrm{Fe}(\mathrm{III})$ complexes exhibited a ligand to metal charge transfer band in the region $400-420 \mathrm{~nm}$. In addition to this, a weak band observed in the region $490-510 \mathrm{~nm}$ which could be assigned to ${ }^{6} \mathrm{~A}_{1 \mathrm{~g}}$ ? ${ }^{4} \mathrm{~T}_{1 \mathrm{~g}}$ transition which suggest an octahedral configuration around the $\mathrm{Fe}(\mathrm{III})$ ion [36] (Scheme 2).

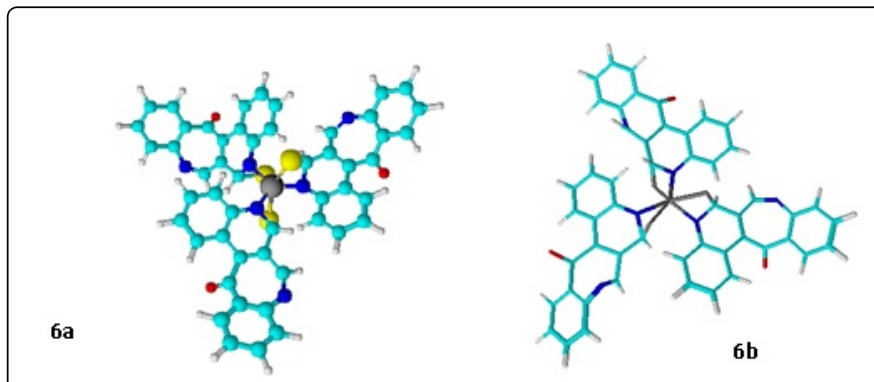

Scheme 2: The three-dimensional structure of Iron(III) complexes containing sulfur and selenium.

\section{Invitro antioxidant activities}

Superoxide anion scavenging activity: In the PMS-NADH-NBT system, superoxide anion derived from dissolved oxygen by PMSNADH coupling reaction reduces NBT. The antioxidant properties of the prepared ligands and $\mathrm{Fe}(\mathrm{III})$ complexes were verified by their catalytic activities in the dismutation of superoxide radicals. The complexes showed to be active catalysts, with a better performance of scavenging ability than ligands. The SOD activity of these complexes was compared with standard BHT and BHA. The decrease of absorbance at $570 \mathrm{~nm}$ with ligands and their complexes indicates the consumption of superoxide anion in the reaction mixture. Thus, complexes process strong superoxide radical scavenging activity than BHT, and $\alpha$-tocopherol (Figure 1).

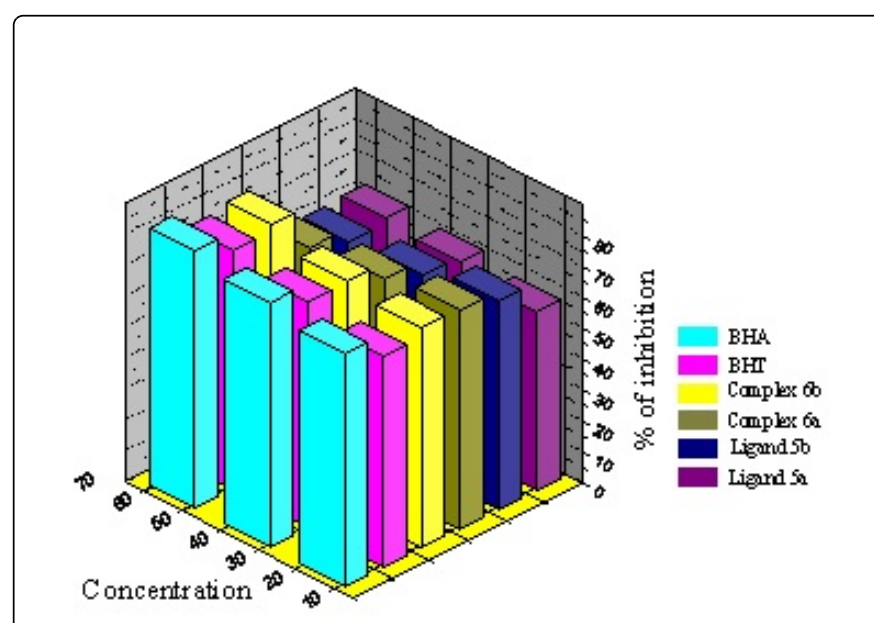

Figure 1: Superoxide anion radical scavenging activity of ligands and their complexes with BHA, BHT, and $\alpha$-tocopherol by the PMSNADH-NBT method (BHA: butylated hydroxyanisole, BHT: butylated hydroxytoluene).

The results were found statistically significant $(\mathrm{p}<0.05)$ the percentage inhibition of superoxide generated by $60 \mu \mathrm{g} / \mathrm{mL}$ concentration of complexes was found to be $67 \%$ for $6 \mathrm{a}$ and $74 \%$ for $6 \mathrm{~b}$ 
which is greater than that of BHT and a-tocopherol (35\% and 28\%) respectively, at same concentration.

\section{Scavenging of hydrogen peroxides}

Hydrogen peroxide itself is not very reactive, but it can be toxic sometimes it may give rise to a hydroxyl radical [37]. Thus, removing $\mathrm{H}_{2} \mathrm{O}_{2}$ is very important for protection of biological systems. Our synthesized iron complexes are capable of scavenging hydrogen peroxide in a concentration-dependent manner was determined according to the method [38]. The scavenging ability of complexes and their ligands on hydrogen peroxide is shown in Figure 2. At $60 \mu \mathrm{g} / \mathrm{mL}$ concentration complex $6 \mathrm{a}$ and $6 \mathrm{~b}$ exhibited 76 and $72 \%$ of scavenging effect over hydrogen peroxide. Thus, statistically these results are significant and followed this order for inhibition (complex 6a>complex $6 \mathrm{~b}>\mathrm{BHA}>\mathrm{BHT}$ ) for hydrogen peroxide.

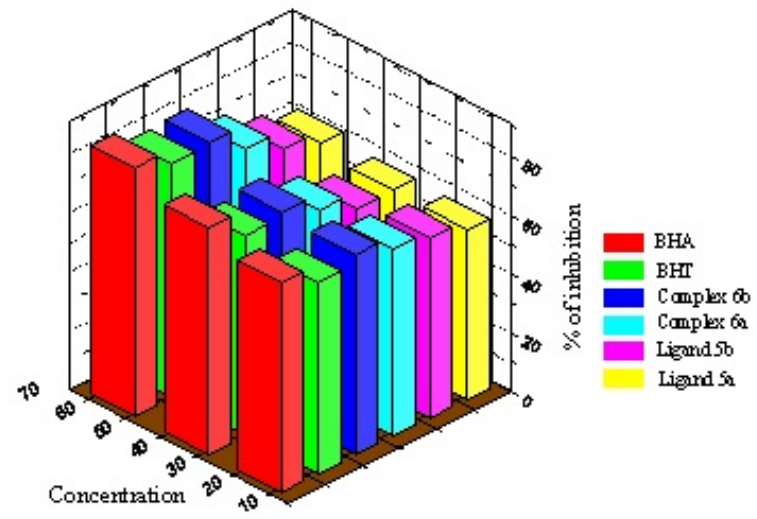

Figure 2: Percentage of inhibition plot for ligands and complexes against BHA, BHT, and $\alpha$-tocopherol.

\section{Hydroxyl radical (HO') scavenging activity}

In the case of scavenging effect of hydroxyl radical we found that the complexes are good scavengers of $\mathrm{OH}$ radicals in a concentrationdependent manner (Figure 3). BHT and BHA are used as standard hydroxyl radical scavenging reagent. The activity of standards compared with complexes indicates the hydroxyl radical scavenging ability increases with decrease in the absorbance at $520 \mathrm{~nm}$ as shown in Figure 3.

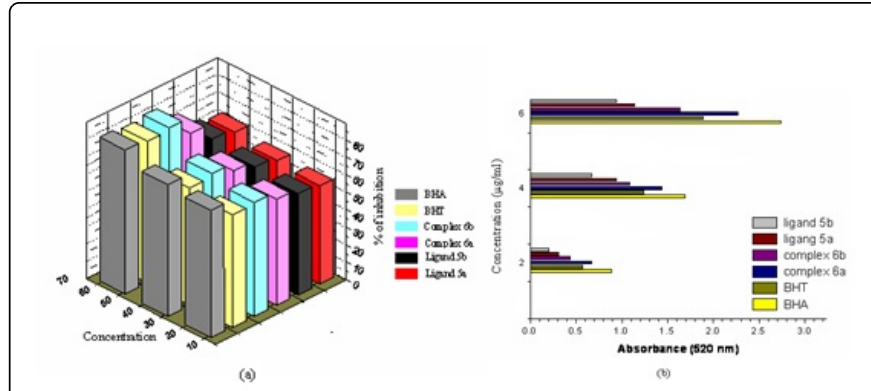

Figure 3: (a) percentage inhibition plot and (b) absorbance plot for hydroxy radical scavenging activity at $(20-60 \mu \mathrm{g} / \mathrm{ml})$ concentration of ligands, complexes, BHA, BHT, and $a$-tocopherol by 1,1diphenyl-2-picrylhydrazyl (DPPH) radicals.

\section{Free radical (DPPH) scavenging activity}

The reduction capability of DPPH radicals was determined by decrease in its absorbance at $517 \mathrm{~nm}$ leads to the activity. The decrease in absorbance of DPPH radical caused by antioxidants because of the reaction between complexes and DPPH radicals progresses, which results in the scavenging of the radical by hydrogen donation. It is visually noticeable as a discoloration. Hence, DPPH is an important substrate to evaluate antioxidant activity $[39,40]$. Figure 4 illustrates significant $(<0.01)$ decrease in the concentration of DPPH radical due to the scavenging ability of complexes and ligands compared to standards. The results indicate that the complexes showed stronger DPPH scavenging activity rather than their ligands. Statistically, the scavenging effect of complexes with DPPH radical decreased in the following order of $\mathrm{BHA}>$ complex $6 \mathrm{a}>\mathrm{BHT}>$ complex $6 \mathrm{~b}>\mathrm{a}$-tocopherol with $64,61,55,48$, and $35 \%$ of inhibition, respectively.

\section{Reducing power}

The reducing capacity of a compound may serve as a significant indicator of its potential antioxidant activity [41]. The antioxidant activity of putative antioxidants have been attributed to various mechanisms, among which are prevention of chain initiation, binding of transition metal ion catalysts, decomposition of peroxides, prevention of continued hydrogen abstraction, reductive capacity, and radical scavenging [42]. The reducing power of complexes increased with decrease in absorbance value. Complex $6 \mathrm{a}$ exhibited stronger reducing power than complex $6 \mathrm{~b}$, may be due to the presence of selenium but this difference between the complexes with ligands were found statistically significant $(\mathrm{p}>0.06)$ with standard compounds followed the order:BHA>complex $6 \mathrm{a}>\mathrm{BHT}>$ ligand $5 \mathrm{a}>$ ligand $5 b>$ complex $6 b>a$-tocopherol which is as shown in the Figure 5 . 


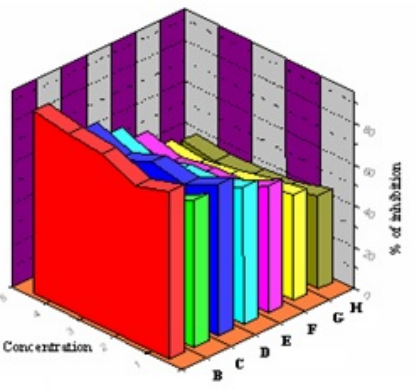

(a)

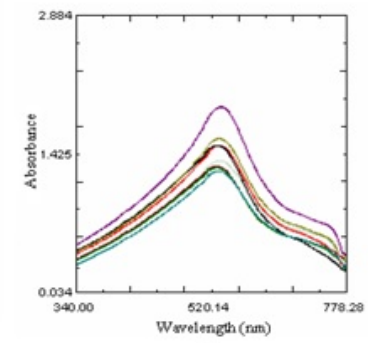

Figure 4: (a) Percentage of inhibition and (b) Absorption plot belongs to complexes and ligands for DPPH free radical scavenging activity at $(20-60 \mu \mathrm{g} / \mathrm{ml})$ concentration with BHA, BHT, and atocopherol. Wherein $\%$ of inhibition plot $\mathrm{B}=\mathrm{BHA}, \mathrm{C}=\mathrm{BHT}$, $\mathrm{D}=\left[\mathrm{Fe}(\mathrm{SBAQ})_{3}\right], \mathrm{E}=\left[\mathrm{Fe}(\mathrm{MBAQ})_{3}\right], \mathrm{F}=5 \mathrm{a}, \mathrm{G}=5 \mathrm{~b}, \mathrm{H}=\alpha$-tocopherol.

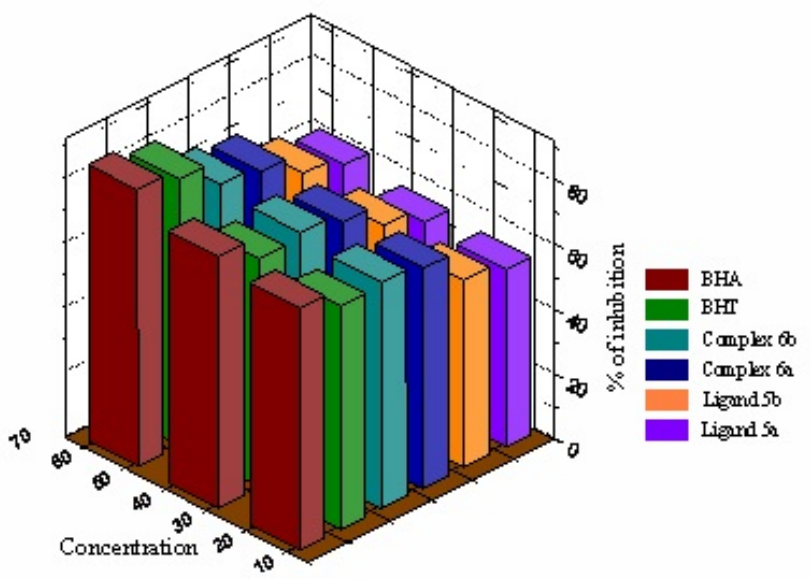

Figure 5: Bar graph showing the reducing power of ligands and complexes with BHA, BHT, and $\alpha$-tocopherol.

\section{Total antioxidant activity determination in linoleic acid emulsion}

The total antioxidant activity of ligands and their complexes was determined by thiocyanate method $[40,43,44]$. Both complexes exhibited effective and powerful antioxidant activity whereas ligands showed comparatively less activity. Results show that the activity was increased with increasing the concentration of complexes. At 20-60 $\mu \mathrm{g} / \mathrm{mL}$ the percentage inhibition of peroxidation in the linoleic acid system was 76,85 , and $94 \%$ for complexes and 71,75 , and $83 \%$ for their ligands, respectively which is greater than $\alpha$-tocopherol (63\%) inhibition at $60 \mu \mathrm{g} / \mathrm{mL}$. On the other hand, percentage inhibition of 60 $\mu \mathrm{g} / \mathrm{mL}$ concentration of standard BHA and BHT was found to be 94 and $95 \%$ (Figure 6).
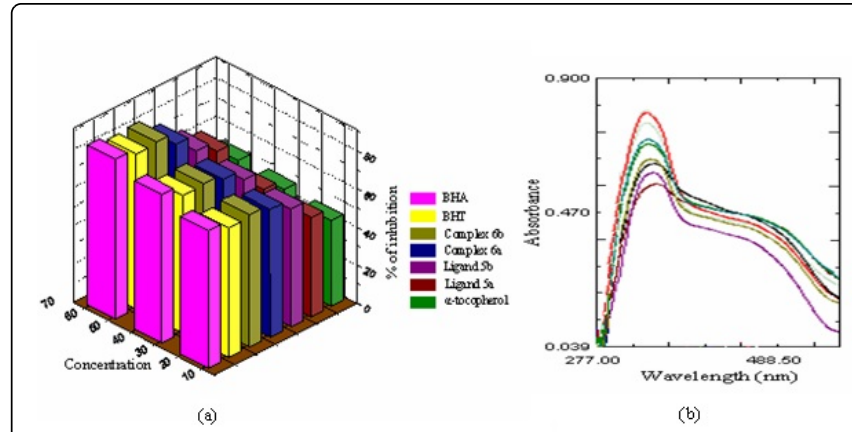

(b)

Figure 6: (a) Percentage of inhibition graph and (b) absorbance plot for the total antioxidant activity at $(20-60 \mu \mathrm{g} / \mathrm{ml})$ concentration of ligands and complexes with BHA, BHT and $\alpha$-tocopherol in the linoleic acid emulsion.

\section{The pUC 19 DNA cleavage studies}

It is now recognized that the extremely reactive $\cdot \mathrm{OH}$ radical derived from $\mathrm{O}_{2}^{-}$and $\mathrm{H}_{2} \mathrm{O}_{2}$ is a cause of DNA strand scission in cellular damage [45]. Figure 7 shows the electrophoretic pattern of DNA after $\mathrm{UV}$-photolysis of $\mathrm{H}_{2} \mathrm{O}_{2}(2.5 \mathrm{mmol} / \mathrm{L})$ in the absence or presence of the complex.

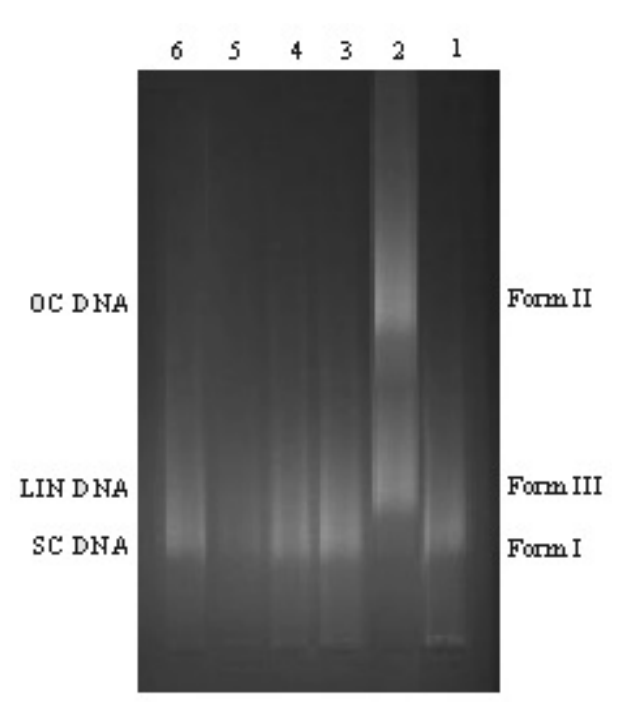

Figure 7: Effects of complexes at $(200-400 \mathrm{mmol} / \mathrm{L})$ on the protection of supercoiled DNA against $\mathrm{OH}$ generated by photolysis at $360 \mathrm{~nm}$ in presence of $\mathrm{H}_{2} \mathrm{O}_{2}$. Lane 1, untreated DNA (control); lane 2, DNA $+\mathrm{H}_{2} \mathrm{O}_{2}$; lane 3, DNA+complex 6a $200 \mathrm{mmol} / \mathrm{L}+2.5$ $\mathrm{mmol} / \mathrm{L} \mathrm{H}_{2} \mathrm{O}_{2}$; lane 4, complex $6 \mathrm{a} 400 \mathrm{mmol} / \mathrm{L}+2.5 \mathrm{mmol} / \mathrm{L} \mathrm{H}_{2} \mathrm{O}_{2}$; lane 5, complex $6 \mathrm{~b} 200 \mathrm{mmol} / \mathrm{L}+2.5 \mathrm{mmol} / \mathrm{L} \mathrm{H}_{2} \mathrm{O}_{2}$; lane 6, complex 6b $400 \mathrm{mmol} / \mathrm{L}+2.5 \mathrm{mmol} / \mathrm{L} \mathrm{H}_{2} \mathrm{O}_{2}$.

The faster-moving band corresponding to the native form of supercoiled circular DNA (scDNA) and the slower-moving band being the open circular form (ocDNA). The UV irradiation of DNA in the presence of $\mathrm{H}_{2} \mathrm{O}_{2}$ (lane 2) caused the cleavage of scDNA to give open coiled DNA (ocDNA) and the linear form (lin DNA), indicating that 
OH generated by UV-photolysis of $\mathrm{H}_{2} \mathrm{O}_{2}$ produced DNA strand scission. The presence of the complexes under investigation suppressed the formation of DNA damage this shows the new complexes able to control oxidative DNA damage, which has been particularly implicated in carcinogenesis [46]. The above results indicate that radicals generated by the complexes may pair up with the $\cdot \mathrm{OH}$ generated by $\mathrm{H}_{2} \mathrm{O}_{2}$ that might be the reason for (lanes 2-5) movement of DNA without cleavage.

\section{Conclusion}

On the basis of the results, it is clearly indicated that the newly synthesized $\mathrm{Fe}(\mathrm{III})$ complexes $\left[\mathrm{Fe}(\mathrm{MBAQ})_{3}\right]$ and $\left[\mathrm{Fe}(\mathrm{SBAQ})_{3}\right]$ containing selenium and sulfur atom have significant antioxidant activity against various invitro antioxidant systems. The various antioxidant mechanisms of ligands and iron complexes may be attributed to their effectiveness as good scavengers of hydrogen peroxide, superoxide, and free radicals. However, the components responsible for the antioxidative activity of both complexes are clearly shows antioxidant activity. Further, these results supported by protective effect against pUC 19 DNA. Therefore, it is suggested that further work could be performed on metal complexes especially of iron as antioxidant compounds to evaluate its invivo effects.

\section{Acknowledgement}

One of the author (Prakash Naik HR) grateful to SC/ST cell Kuvempu University for providing JRF and Director NMR research institute (IISc) Indian Institute of Science Bangalore for providing spectral facilities.

\section{References}

1. Gutteridgde JMC (1995) Free radicals in disease processes:A complication of cause and consequence. Free Radic Res Comm 19: 141.

2. Tiwari A (2001) Imbalance in antioxidant defence and human diseases: Multiple approach of natural antioxidants therapy. Curr Sci 81: 1179-1187.

3. Joyce GF (1987) Oxygen radicals in disease. Adv Drug Reac Bull 127: 476.

4. Iwaoka M, Tomoda SA (1994) Model Study on the Effect of an Amino Group on the Antioxidant Activity of Glutathione Peroxidase. J Am Chem Soc 116: 2557-2561.

5. Stadtman TC (1980) Selenium-dependent enzymes. An Rev Biochem 49: 93-110.

6. Klayman DL, Güther WH (1973) Organic selenium compounds: their chemistry and biology. John Wiley and Sons, Inc., New York:John Wiley and Sons, Inc, p: 728.

7. Spallholz JE (1994) On the nature of selenium toxicity and carcinostatic activity. Free Radic Biol Med 17: 45-64.

8. Olson OE (1986) Selenium toxicity in animals with emphasis on man. J Am Coll Toxicol 5: 45-70.

9. Magos L (1980) The interactions of selenium with cadmium and mercury Crit Rev Toxicol 8: 1-42.

10. Fishbein L (1986) Prespectives on selenium anticarcinogenicity. Toxicol Envi Chem 12: 1-30.

11. Tampo YM, Yonaha M (1992) Antioxidant mechanism of Mn II; in phospholipid peroxidation. Free Radical Biol Med 13: 115-120.

12. Sigel A, Sigel H (1999) Interactions Between Free Radicals and Metal Ions in Life Process-Metal Ions in Biological Systems, Marcel Dekker Inc, New York, p: 797.

13. Riley DP (1999) Functional Mimics of Superoxide Dismutase Enzymes as Therapeutic Agents. Chem Rev 99: 2573-2588.
14. Autzen S, Korth H, Boese R, Groot HG, Sustmann R (2003) Studies of Pyridinyl-containing 14-membered Macrocyclic Copper II; Complexes. Eur J Inorg Chem 34: 1401-1410.

15. Day BJ (2004) Catalytic antioxidants: a radical approach to new therapeutics. Drugs Discov Today 9: 557-566.

16. Fenton HJH (1894) Oxidation of tartaric acid in presence of iron. J Chem Soc Trans 65: 899-910.

17. Haber F, Willstätter R (1931) Unpairedness and radical chains in the reaction mechanism of organic and enzymic process. Ber Deutsch Chem Ges 64: 2844.

18. Haber F (1934) The catalytic decomposition of hydrogen peroxide by iron salts. J Weiss Proc Roy Soc London 147: 332-351.

19. Halliwell B, Gutteridge JMC (1990) DNA damage by oxygen-derived species Its mechanism and measurement in mammalian systems. Meth Enzymol 86: 1-85.

20. Goldstein S, Meyerstein D, Czapski G (1993) The Fenton reagents. Free Rad Biol Med 15: 435-445.

21. Nozaki T, Ushio H, Mago G, Matsumoto N, Okawa H, et al. (1994) Ligand-field control in the self-assembly of polymeric metal-complexescopper ii; complexes with quadridentate schiff-base ligands involving an imidazole moiety. J Chem Soc Dalton Trans 16: 2339-2345.

22. Fielden EM, Rotilio G (1984) Copper Proteins and Copper Enzymes. CRC Press, Boca Raton, pp: 27-61.

23. Kaltwasser JP, Werner E, Niechzial M (1987) Bioavailability and therapeutic efficacy of bivalent and trivalent iron preparations. ArzForsch Drug Res 37: 122-129.

24. Rauch P, Kas J, Ranny M (1990) Iron bioavailability from its complex with sucrose. Food Chem 36: 129-134.

25. Mitsuda H, Yuasumoto K, Iwami K (1996) Antioxidation action of indole compounds during the autoxidation of linoleic acid. Eiyo to Shokuryo 19: 210-214.

26. Duh PD, Tu YY, Yen GC (1999) Antioxidant activity of water extract of Harng Jyur Chrysanthemum morifolium Ramat. Food Sci Technol 32: 269-277.

27. Gulcin I, Buyukokuroglu ME, Oktay M, Kufrevioglu OI (2003) Determination of in vitro antioxidant activity of fennel (Foeniculum vulgare) seed extracts. J Ethnopharmacol 86: 1.

28. Gulcin I, Oktay M, Kirecci E, Kufrevioglu OI (2003) Screening of antioxidant and antimicrobial activities of anise (Pimpinella anisum L.) seed extracts. Food Chem 83: 371-382.

29. Ye XY, Wang HX, Liu F, Ng TB (2000) Ribonuclease, cell-free translationinhibitory and superoxide radical scavenging activities of the ironbinding protein lactoferrin from bovine milk. Intern J Biochem Cell 32: 235-241.

30. Gulcin I, Buyukokuroglu ME, Oktay M, Kufrevioglu IO (2003) Antioxidant and analgesic activities of turpentine of Pinus nigra Arn Subsp. Pallsiana Lamb, Holmboe. J Ethnopharmacol 86: 51.

31. Shimada K, Fujikawa K, Yahara K, Nakamura T (1992) Antioxidative properties of xanthan on the autoxidation of soybean oil in cyclodextrin emulsion. J Agri Food Chem 40: 945.

32. Bernadou J, Pratviel G, Bennis F, Girardet M, Meunier B (1989) Potassium monopersulfate and a water-soluble manganese porphyrin complex, as an efficient reagent for the oxidative cleavage of DNA. Biochem 28: 7268 .

33. Dhar S, Senapati D, Das PK, Chattopadhyay P, Nethaji M (2003) Ternary copper complexes for photocleavage of DNA by red light: direct evidence for sulfur-to-copper charge transfer and d-d band involvement. J Am Chem Soc 125: 12118.

34. Prakash Naik HR, Bhojya Naik HS, Ravikumar Naik TR, Raja Naik H, Gouthamchandra K, et al. (2009) Synthesis of novel benzo[h]quinolines: Wound healing, antibacterial, DNA binding and in vitro antioxidant activity. European J Med Chem 44: 981.

35. Ayman AH, Ahmed H, Ahmed Omran A, Gamal Sherbiny ME (2006) Synthesis, Characterization and Biological Evaluation of Some Methylenedisalicylic Acid Complexes. J App Sci Res 21: 44 
Citation: Prakash Naik HR, Rajappa JJ, Karmakar B, Raja Naika H, Ramachandra Naik M, et al. (2018) Synthesis of Fe(III) Complexes as Antioxidants and DNA Cleavage Protectors. Nat Prod Chem Res 6: 317. doi:10.4172/2329-6836.1000317

Page 8 of 8

36. Moon D, Kim J, Lah MS (2006) Synthesis and Characterization of Mononuclear Octahedral Fe III; Complex Containing a Biomimetic Tripodal Ligand, N-Benzimidazol-2-ylmethyl; iminodiacetic Acid. Bull Korean Chem Soc 27: 1597.

37. Ruch RJ, Cheng SJ, Klaunig JE (1989) Prevention of cytotoxicity and inhibition of intercellular communication by antioxidant catechins isolated from Chinese green tea. Carcinog 10: 1003.

38. Meir S, Kanner J, Akiri B, Hadas SP (1995) Determination and Involvement of Aqueous Reducing Compounds in Oxidative Defense Systems of Various Senescing Leaves. J Agric Food Chem 43: 181.

39. Duh PD, Tu YY, Yen GC (1999) Antioxidant activity of water extract of Harng Jyur Chrysanthemum morifolium Ramat. Food Sci Technol 32: 269-277.

40. Chang LW, Yen WJ, Huang SC, Duh PD (2002) Antioxidant activity of sesame coat. Food Chem 78: 347.
41. Gulcin I, Buyukokuroglu ME, Oktay M, Kufrevioglu OI (2002) On the in vitro antioxidative properties of melatonin. J Pineal Res 33: 167.

42. Diplock AT (1997) Will the good fairies please prove us that vitamin E lessens human degenerative disease. Free Radical Res 27: 511.

43. Amarowicz R, Naczk M, Shahidi F (2000) Antioxidant activity of crude tannins of canola and rapeseed hulls. JAOCS 77: 957.

44. Wiseman H, Halliwell B (1996) Damage to DNA by reactive oxygen and nitrogen species: Role in inflammatory disease and progression to cancer. Biochem J 313: 17.

45. Feig DI, Reid TM, Loeb LA (1994) Reactive oxygen species in tumorigenesis. Cancer Res 54: 1890.

46. Routledge MN, Wink DA, Keefer L, Dipple A (1994) DNA sequence changes induced by two nitric oxide donor drugs in the supF assay. Chem Res Toxicol 7: 628 